\title{
Nucleation and Growth Mechanisms in Cu-Co Films
}

\author{
M. del C. Aguirre, ${ }^{a, b,{ }^{*}}$ H. Núñez Coavas, ${ }^{b}$ L. M. Fabietti, ${ }^{a, b}$ S. E. Urreta ${ }^{b}$ \\ ${ }^{a}$ Instituto de Física Enrique Gaviola de Córdoba, CONICET-UNC, Córdoba, Argentina \\ ${ }^{b}$ Facultad de Matemática, Astronomía y Física, FAMAF-UNC, \\ Medina Allende s/n, Ciudad Universitaria, 5000 Córdoba, Argentina
}

*Corresponding Author E-mail: carmenaguirre@famaf.unc.edu.ar

Tel: + 54-351-4334051 ext 125. Fax: + 54-351-4334054 


\section{1- Current response during deposition}

An eventual contribution of the less noble component of the substrate ( $\mathrm{Zn}$ from brass during $\mathrm{Cu}$ deposition, or $\mathrm{Co}$ from the $\mathrm{Cu}-\mathrm{Co}$ alloy during the bi-layer $\mathrm{Cu}$ deposition) to the current response during deposition was investigated.

Room temperature anodic linear sweep voltammetery (ALSV), and linear polarization (LP) curves were performed. The LP method is of special importance in this study because the kinetics of corrosion of copper, brass and $\mathrm{Co}_{\mathrm{x}} \mathrm{Cu}_{100-\mathrm{x}} /$ brass bi-layer foils used as electrodes may be compared by distinctive $\mathrm{E}_{\mathrm{mix}}$. The LP and ALSV curves were built at $1 \mathrm{mV} / \mathrm{s}$ from $-1 \mathrm{~V}$ to $+1 \mathrm{~V}$ in the electrolytic bath $0.1 \mathrm{M} \mathrm{H}_{3} \mathrm{BO}_{3} / \mathrm{H}_{2} \mathrm{SO}_{4} \mathrm{pH} 3$, free of metallic ions.

From cathodic and anodic branches in Figure S1.A, kinetic parameters determining the corrosion resistance may be estimated. $\mathrm{Co}_{\mathrm{x}} \mathrm{Cu}_{100-\mathrm{x}} /$ brass exhibits corrosion or mix potential at $(+0.056 \mathrm{~V}$ vs. $\mathrm{Ag} / \mathrm{AgCl}$ ) slightly more positive than $\sim+0.04 \mathrm{~V}$ vs. $\mathrm{Ag} / \mathrm{AgCl}$ of brass and copper foils, with copper foil showing the lowest corrosion current density.

The ALSV curves (Figure S1.B) evidence that the oxidation/dissolution properties of the three different substrates used are located in the range from +0.04 to $+1 \mathrm{~V} v s$. $\mathrm{Ag} / \mathrm{AgCl}$. These potentials are far from that used for deposition, $-0.8 \mathrm{~V} v \mathrm{~s} . \mathrm{Ag} / \mathrm{AgCl}$. Then, no significant contributions from the less noble component of the brass substrate $(\mathrm{Zn})$ and the bi-layer $(\mathrm{Co})$ are expected to the current response during electrodeposition.

$\mathrm{Zn}$ dissolution from the substrate (de-alloying) was further analyzed; a new anodic polarization curve (ALSV) of the brass, immersed in the bath $0.1 \mathrm{M} \mathrm{H}_{3} \mathrm{BO}_{3}+\mathrm{H}_{2} \mathrm{SO}_{4} \mathrm{pH} 3$, free of metallic $\mathrm{Co}^{2+}$, was built. The anodic linear sweep voltammetry was scanned from $-1 \mathrm{~V}$ to $+1 \mathrm{~V}$ at $1 \mathrm{mV} / \mathrm{s}$. 

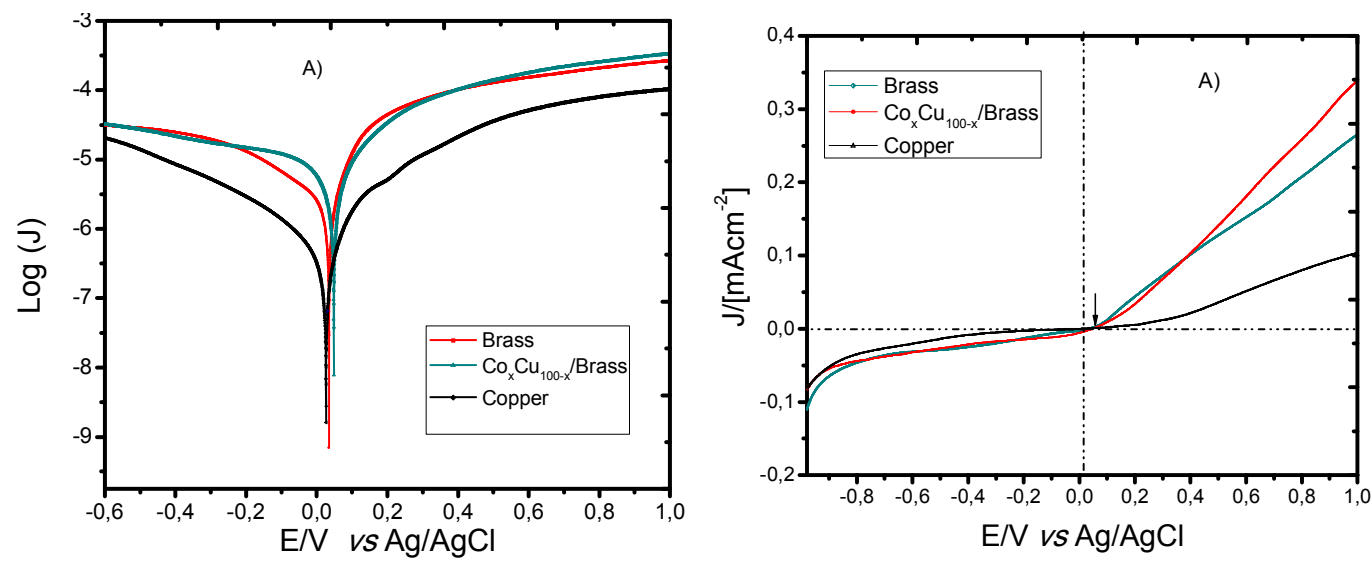

Figure S1. A) LP curves and B) Anodic LSV curves, of $0.1 \mathrm{MH}_{3} \mathrm{BO}_{3} / \mathrm{H}_{2} \mathrm{SO}_{4}$ solution of $\mathrm{pH} 3$, free of metallic $\mathrm{Cu}^{2+}$, on different substrates: Copper (black), Brass (red) and $\mathrm{Co}_{\mathrm{x}} \mathrm{Cu}_{100-\mathrm{x}} / \mathrm{Brass}$ (blue).

This curve is represented in Figure S2 A, and its corresponding LP curve in Figure S2 B, which evidences a value of $\mathrm{E}_{\text {mix }} \sim+0.037 \mathrm{~V} v s \mathrm{Ag} / \mathrm{AgCl}$ on the brass substrate. This value is very close to that corresponding to the more noble copper foil $(+0.04 \mathrm{~V} v s . \mathrm{Ag} / \mathrm{AgCl})$ in the same solution, free of metallic ions. The potential $E_{\text {mix }}$ of brass is far from $E_{\text {eq }}$ calculated by Nernst equation for the $\mathrm{Co}^{2+} / \mathrm{Co}$ couple, resulting $-0.525 \mathrm{~V} v$ s. $\mathrm{Ag} / \mathrm{AgCl}$ and also far from the conditions applied in the electrodeposition (-0.8V vs. $\mathrm{Ag} / \mathrm{AgCl})$.
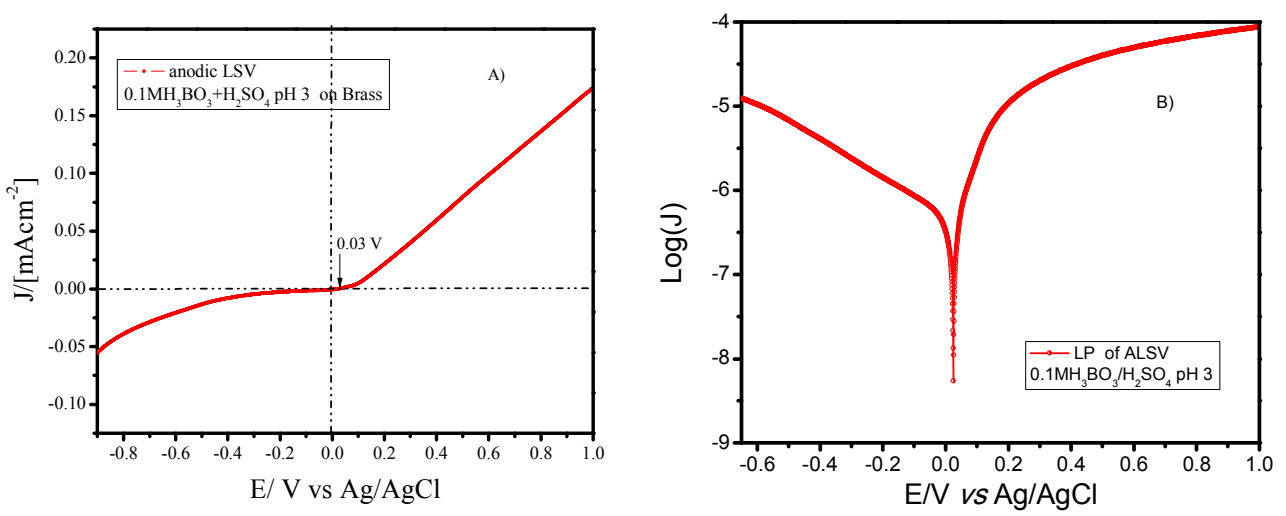

Figure S2. A) ALSV of $\mathrm{H}_{3} \mathrm{BO}_{3} / \mathrm{H}_{2} \mathrm{SO}_{4} \mathrm{pH} 3$ on brass. B) The corresponding LP curve.

In order to further confirm that $\mathrm{Zn}$ dissolution may be neglected, the composition of the brass substrate before and after different deposition treatments were determined by EDS. $\mathrm{Cu}$ and $\mathrm{Zn}$ 
contents were examined in a foil mechanically polished in the conditions of our work, and in substrates corresponding to $\mathrm{Co}$ and the bi-layer $\mathrm{CoCu} / \mathrm{Cu} /$ brass samples, after complete exfoliation of the deposited film. These results are shown below in Figure S3 and the compositions are listed in Table A. They are statistically indistinguishable.

Table A. Composition Analysis of Brass Substrates

\begin{tabular}{lll}
\hline \hline \multirow{2}{*}{ Sample } & \multicolumn{2}{c}{ Substrate composition } \\
& at.\% $\mathrm{Cu} \pm 0.5$ & at.\% $\mathrm{Zn} \pm 0.5$ \\
\hline $\begin{array}{l}\text { Mechanically polished } \\
\alpha \text {-brass }\end{array}$ & 71.4 & 28.6 \\
$\begin{array}{l}\text { Co95Cu.08V30min } / \mathrm{Cu} \\
-0.8 \mathrm{~V} \mathrm{15min} / \mathrm{brass}\end{array}$ & 71.5 & 28.5 \\
$(\mathrm{Co}-0.8 \mathrm{~V} 30 \mathrm{~min}) / \mathrm{brass}$. & 71.3 & 28.7 \\
\hline
\end{tabular}

Composition values listed in Table A show no significant changes in the substrate alloy composition during different electrodeposition assays, which is consistent with negligible dealloying processes during electrodeposition.

\section{2- Boric acid incorporation to the electrolyte}

Boric boric acid is added to the electrolyte to control local $\mathrm{pH}$, which may increase due to proton reduction, leading to a parallel hydrogen evolution reaction (HER). Controlling $\mathrm{OH}^{-}$ generation, the formation of hydroxilated Co species [Ref. 21 in the text] diminishes. This

guarantees the major quantity of free $\mathrm{Co}^{2+}$ ions species in the solution, eliminating hydroxides incorporation into the deposit.

Boron content in the bi-layer film $\mathrm{Co}_{\mathrm{x}} \mathrm{Cu}_{100-\mathrm{x}}(-0.8 \mathrm{~V} 30 \mathrm{~min}) / \mathrm{Cu}(-0.8 \mathrm{~V} 15 \mathrm{~min}$, and $\mathrm{Co}(-$ $0.8 \mathrm{~V} 30 \mathrm{~min}$ ) films previously exfoliated from the substrate, were measured in a microprobe JEOL JXA 8230 , with a LDEz K $\alpha$ crystal $(188,53 \mathrm{~mm})$ and a current of $50 \mathrm{nA}$. No traces of Boron could be detected in these films with this technique. 
Smaller concentrations were further explored in the bi-layer film by the ICP-MS method in an AGILENT 7500cx device (low detection limit $=0.539 \mathrm{ppm}$; low quantification limit $=1.851 \mathrm{ppm}$ ) . This film, with the highest exposition time to $\mathrm{H}_{3} \mathrm{BO}_{3} 0.1 \mathrm{M}$, is found to contain only $(1.9 \pm 0.1) \mathrm{ppm}$ of Boron, a value quite close to the low quantification limit. These results are consistent with the shape of the $\mathrm{CV}$ reduction wave up to $-0.8 \mathrm{~V}$ vs. $\mathrm{Ag} / \mathrm{AgCl}$, which shows no evidence of boric acid reduction with protons nor of its incorporation into the film.

\section{Mechanically polished $\alpha-\beta$ rass}
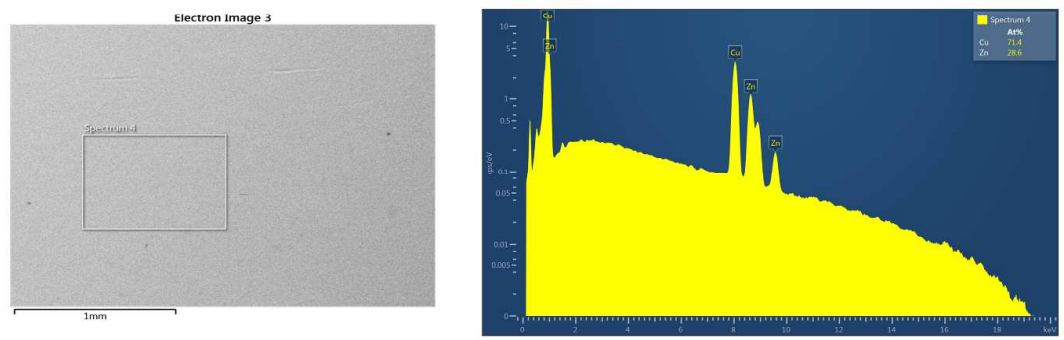

$\mathrm{C} 095 \mathrm{Cu} .08 \mathrm{~V} 30 \mathrm{~min} / \mathrm{Cu}-0.8 \mathrm{~V} 15 \mathrm{~min}) / \mathrm{brass}$
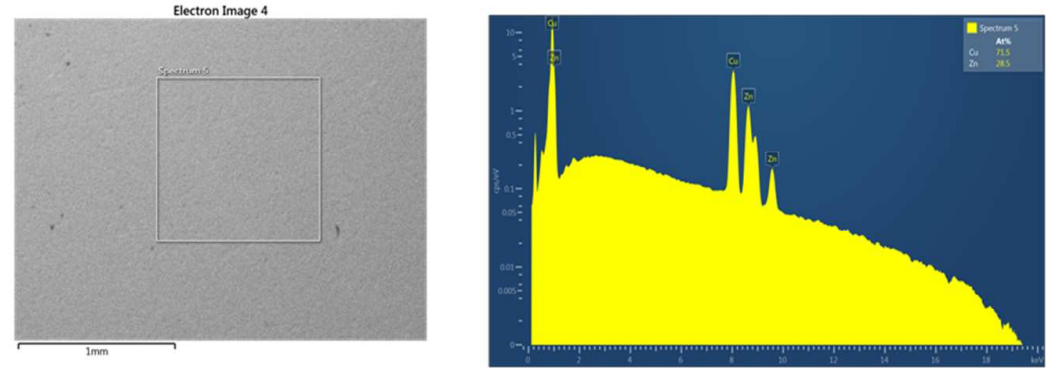

(Co-0.8V30min)/brass.
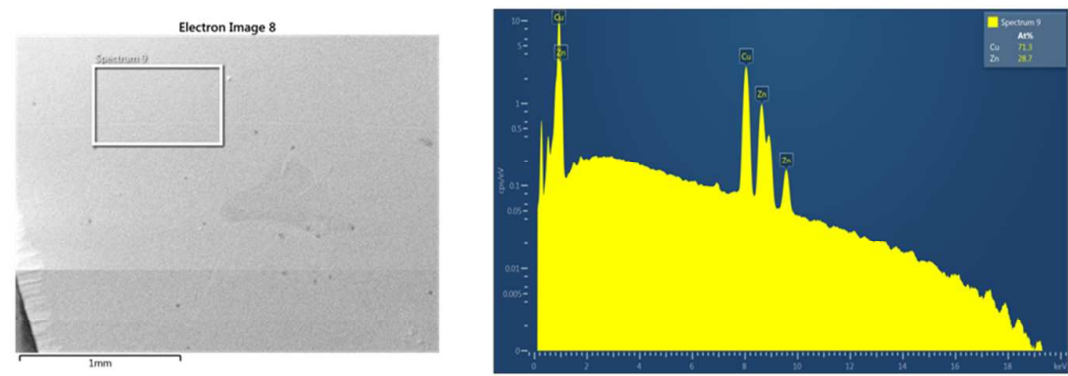

Figure S3. EDS spectra corresponding to the brass substrates used, after complete exfoliation of the deposited film. 